\title{
Effects of green tea, matcha tea and their components epigallocatechin gallate and quercetin on MCF-7 and MDA-MB-231 breast carcinoma cells
}

\author{
LENNARD SCHRÖDER $^{1 *}$, PHILIP MARAHRENS ${ }^{2 *}$, JULIAN G. KOCH ${ }^{1}$, HELENE HEIDEGGER $^{1}$, \\ THERESA VILSMEIER ${ }^{1}$, THUY PHAN-BREHM ${ }^{1}$, SIMONE HOFMANN ${ }^{1}$, SVEN MAHNER1, \\ UDO JESCHKE $^{1}$ and DAGMAR U. RICHTER ${ }^{2}$
}

\begin{abstract}
${ }^{1}$ Department of Obstetrics and Gynecology, University Hospital, Ludwig Maximilians University (LMU) of Munich, D-80337 Munich; ${ }^{2}$ Department of Obstetrics and Gynecology, University of Rostock, D-18059 Rostock, Germany
\end{abstract}

Received April 23, 2018; Accepted October 1, 2018

DOI: $10.3892 /$ or.2018.6789

\begin{abstract}
We investigated the anticarcinogenic potential of green tea and its components epigallocatechin gallate (EGCG) and quercetin, as well as tamoxifen, on MCF-7 and MDA-MB-23 breast cancer cells. Using high-performance liquid chromatography, the quantity of EGCG and quercetin in green tea was analyzed. The receptor status of the cells was confirmed immunohistochemically. Various viability and cytotoxicity tests were later performed to investigate the effects of the substances. After incubating the cells with green tea extract, EGCG, quercetin and tamoxifen, a decrease in viability (MTT test) or proliferation (BrdU assay) was found in all cell tests with varying effects, depending on the assay used. The effects were similar in both cell lines. This work confirmed that EGCG and quercetin are contained in green tea and that both substances in pure form and as green tea have an anticarcinogenic effect on both estrogen receptor-positive and -negative breast cancer cells. This effect could also be demonstrated with tamoxifen in both cell lines (MTT and BrdU assays). These results suggest that the effects observed in these experiments are not generated only via estrogen receptor-mediated pathways.
\end{abstract}

\section{Introduction}

After water, tea is the most commonly consumed beverage worldwide (1). Even in Western countries, such as Germany,

Correspondence to: Professor Udo Jeschke, Department of Obstetrics and Gynecology, University Hospital, Ludwig Maximilians University (LMU) of Munich, Maistrasse 11, D-80337 Munich, Germany

E-mail: udo.jeschke@med.uni-muenchen.de

*Contributed equally

Key words: green tea, matcha tea, catechins, epigallocatechin gallate, quercetin, breast cancer tea consumption is increasing. In 2015, an average consumption of 28 liters per capita was registered, corresponding to approximately 20,000 tons of total domestic tea consumption. Since 2005, the share of green tea (2005: 20\%) against black tea (2005: $80 \%$ ) has increased to $30 \%$ (2). Similar to black tea, green tea is made from the leaves of the tea plant Camellia sinensis (1).

Recently, matcha tea (MT) has been gaining in popularity. The substrate concentrations are higher than that in other green teas because the leaves are ground with a ceramic mill to a fine powder that is later dissolved in hot water and completely consumed. Fujioka et al published a study in 2016 in which they observed that the protective effect of MT against oxygen radicals is significantly higher than the effect of normal tea leaves due to increased catechin levels (3).

Research on polyphenols in green tea (GT) has revealed considerable health benefits (4). The polyphenol family includes the flavonoids which, in turn, incorporate flavanols and catechins. Approximately $30 \%$ by mass of the dry substance of fresh tea leaves is made up of phenolic compounds. In GT, $90 \%$ of these polyphenolic compounds are catechins. The most abundant catechin in GT is epigallocatechin gallate (EGCG) (5). Epigallocatechin (EGC), epicatechin gallate (ECG) and epicatechin (EC) are also catechins found in GT. However, these only make up 3-6\% (EGC, ECG) and 1-3\% (EC) of the dry mass. Other components of the tea leaves by percentage of dry mass are proteins $(15 \%)$, amino acids (4\%), caffeine (4\%), raw fibers (26\%), lipids (7\%), other carbohydrates $(7 \%)$, pigments, such as chlorophyll and carotenoids (2\%) and minerals (5\%) (6). A cup of GT (100 ml) contains approximately 20-100 mg of EGCG. The US Department of Agriculture states that $200 \mathrm{mg}$ of EGCG are contained in $100 \mathrm{~g}$ of boiled GT $(7,8)$.

It was demonstrated in various studies that EGCG and quercetin exhibit anticancer activity. Besides steroid receptor (9) and PPAR $\gamma$ receptor (10) interaction, other assumed mechanisms of action include interaction with the PI3K/Akt/mTOR signaling pathway (11), VEGF (12), the the $67-\mathrm{kDa}$ laminin receptor (67-LR) (13), p53, Bax protein (14) and Bcl-2 (15). 
In the present study, we analyzed the effects of GT and MT, as well as their components EGCG and quercetin, on MCF-7 and MDA-MB-231 breast carcinoma cells.

\section{Materials and methods}

Breast cancer cell lines and preparation of the test substances. MCF-7 (HTB-22 ${ }^{\mathrm{TM}}$; ATCC; American Type Culture Collection, Manassas, VA, USA) $\left(\mathrm{ER}^{+}, \mathrm{PR}^{+}\right)$and MDA-MB-231 (HTB-26 ${ }^{\mathrm{TM}}$; ATCC) (ER', PR') cell lines were purchased commercially. Green tea (GT) was dissolved in water or $70 \%$ ethanol and was added to the cell culture at two different concentrations. One gram of the MT powder or coarsely ground Chinese tea leaves were weighed and were later dissolved in $10 \mathrm{ml}$ of distilled water or $70 \%$ ethanol. The solutions were heated in a microwave (Discover SP; CEM Corp., Matthews, NC, USA), with the water extracts at $70^{\circ} \mathrm{C}$ and $80 \mathrm{~W}$ for $20 \mathrm{~min}$ and the ethanol extracts at $60^{\circ} \mathrm{C}$ and $80 \mathrm{~W}$ for $20 \mathrm{~min}$. The extracts were subsequently centrifuged (1250 x g, $10 \mathrm{~min}$ ), and the supernatant was later filtered and concentrated by evaporation to a third of the starting solution using a vacuum concentrator (Eppendorf Concentrator S301; Eppendorf, Hamburg, Germany) at $45^{\circ} \mathrm{C}$. The extracts were frozen at $-80^{\circ} \mathrm{C}$ for storage. Before application, the tea extracts were centrifuged $(10.410 \mathrm{x}$ g for $10 \mathrm{~min})$ again after thawing.

EGCG was dissolved in distilled water and tested at seven different concentrations in the cell cultures. Quercetin was dissolved in 50\% DMSO and tested at three different concentrations in the cell cultures. Tamoxifen and estradiol solutions were dissolved in $70 \%$ ethanol and examined at a single concentration.

High-performance liquid chromatography. To evaluate the concentration of EGCG and quercetin in GT and MT, highperformance liquid chromatography (HPLC) was performed. After starting the ClarityChrom ${ }^{\circledR}$ (Knauer $\mathrm{GmbH}$, Berlin, Germany), the sample syringe was filled with $20 \mu \mathrm{l}$ of the extract to be tested (GT, MT, quercetin and EGCG) and analyzed for $40 \mathrm{~min}$. The results were analyzed using ClarityChrom software (version 1670-2). Since the concentrations of the active substances were known, the quantity of the pure substance contained in the tea extract could later be calculated by crossmultiplication.

ATP luminescence test. The ATP luminescence test assessed the viability of the cells at different substrate concentrations. Next, $100 \mu \mathrm{l} /$ well cell suspensions was transferred to a 96-well plate for cell incubation for $24 \mathrm{~h}$ at $37^{\circ} \mathrm{C}$ in $5 \% \mathrm{CO}_{2}$. After the addition of $1 \mu \mathrm{l} /$ well of the extract, further cell incubation was performed for $48 \mathrm{~h}$ at $37^{\circ} \mathrm{C}$ and $5 \% \mathrm{CO}_{2}$. The CellTiter-Glo (Promega, Mannheim, Germany) substrate was mixed with the CellTiter-Glo (Promega) buffer and $100 \mu \mathrm{l} /$ well was added. After $10 \mathrm{~min}$ of incubation at room temperature, the cell culture-reagent mixtures were added to a non-transparent 96-well plate (to avoid light spill to adjacent wells) and were measured using a luminescence reader in the CellTiter-Glo program (Promega).

Proliferation measurement using the MTT assay. Cell proliferation was analyzed using MTT (Roche, Mannheim,
Germany). After incubation of cells $(500,000 / \mathrm{ml})$ for $24 \mathrm{~h}$ in the absence or presence of different substrate concentrations, the MTT-labeled reagent was added at a final concentration of $0.5 \mathrm{mg} / \mathrm{ml}$ and was later incubated again for $4 \mathrm{~h}$. During this time, the metabolically active cells transformed the yellow tetrazolium salt MTT to purple-colored formazan crystals. After adding the solubilization solution, the plates were incubated overnight in a humidified atmosphere at $37^{\circ} \mathrm{C}$. With a microplate reader (Model 680; Bio-Rad Laboratories, Hercules, CA, USA), the color intensity was measured at $570 \mathrm{~mm}$ using a reference wavelength of $650 \mathrm{~nm}$.

BrdU proliferation assay. Cell proliferation was analyzed using a 5-bromo-2'-deoxyuridine (BrdU) labeling and detection kit (Roche). MCF7 and MDA-MB-23 cells $(500,000 / \mathrm{ml})$ were grown in 96-well tissue culture plates for $24 \mathrm{~h}$ in the absence or presence of different substrate concentrations. After labeling with BrdU for $3 \mathrm{~h}$, the cells were fixed, and BrdU incorporation into DNA was measured by ELISA. Cellular proliferation inhibition was expressed relative to the controls $(100 \%) \pm \mathrm{SD}$.

Neutral Red uptake assay. Cellular viability was analyzed using the Neutral Red uptake assay (Sigma-Aldrich, Steinheim, Germany). Next, $100 \mu \mathrm{l} /$ well cell suspension was transferred to a 96-well plate for cell incubation for $24 \mathrm{~h}$ at $37^{\circ} \mathrm{C}$ in $5 \% \mathrm{CO}_{2}$. After the addition of $1 \mu \mathrm{l} /$ well extract, further cell incubation was performed for $24 \mathrm{~h}$ at $37^{\circ} \mathrm{C}$ in $5 \% \mathrm{CO}_{2}$. The medium was replaced with Dulbecco's modified Eagle's medium (DMEM) without additives ( $\mathrm{pH}$ adjusted to 7.2) and 3\% Neutral Red test reagent was added. After $60 \mathrm{~min}$ of incubation at $37^{\circ} \mathrm{C}$ in $5 \% \mathrm{CO}_{2}$, the medium was removed, and the wells were rinsed with $200 \mu \mathrm{l} /$ well of phosphate-buffered saline (PBS). Next, $100 \mu \mathrm{l} /$ well of Neutral Red solution was added, and the wells were placed on a plate vibrator. Finally, the wells were measured using an ELISA reader at $570 \mathrm{~nm}$ using a reference wavelength of $655 \mathrm{~nm}$.

pH measurement. The $\mathrm{pH}$ was measured using a glass electrode. The electrode was calibrated before each measurement series.

Oxidative stress. The hydrogen peroxide colorimetric/fluorometric assay kit (BioVision Inc., Milpitas, CA, USA) was used to determine whether free oxygen radicals (ROS, reactive oxygen species) were produced. The quantity of hydrogen peroxide $\left(\mathrm{H}_{2} \mathrm{O}_{2}\right)$ produced was determined photometrically, with the concentration of $\mathrm{H}_{2} \mathrm{O}_{2}$ being proportional to the measured optical density. After incubation, OxiRed ${ }^{\mathrm{TM}}$ (LinRed IHC, Dossenheim, Germany) was dissolved in $220 \mu \mathrm{l}$ of DMSO (Sigma-Aldrich) and horseradish peroxidase (LinRed IHC, HRP) in $220 \mu \mathrm{l}$ of $\mathrm{H}_{2} \mathrm{O}_{2}$-containing assay buffer. Next, $50 \mu \mathrm{l}$ of the cell culture supernatant was pipetted on 96-well plates, and $\mathrm{H}_{2} \mathrm{O}_{2}$ dilution series with concentrations of 0,1 , 2, 3, 4 and $5 \mathrm{nmol} /$ well $\mathrm{H}_{2} \mathrm{O}_{2}$ was prepared. Fifty microliters of reaction mixture (48 $\mu \mathrm{l}$ of $\mathrm{H}_{2} \mathrm{O}_{2}$-containing assay buffer + $1 \mu 1$ of HRP solution $+1 \mu 1$ of OxiRed ${ }^{\mathrm{TM}}$ solution, LinRed IHC) was added. The samples were vortexed and incubated for $10 \mathrm{~min}$ at room temperature before undergoing measurement using an ELISA reader at $570 \mathrm{~nm}$. 

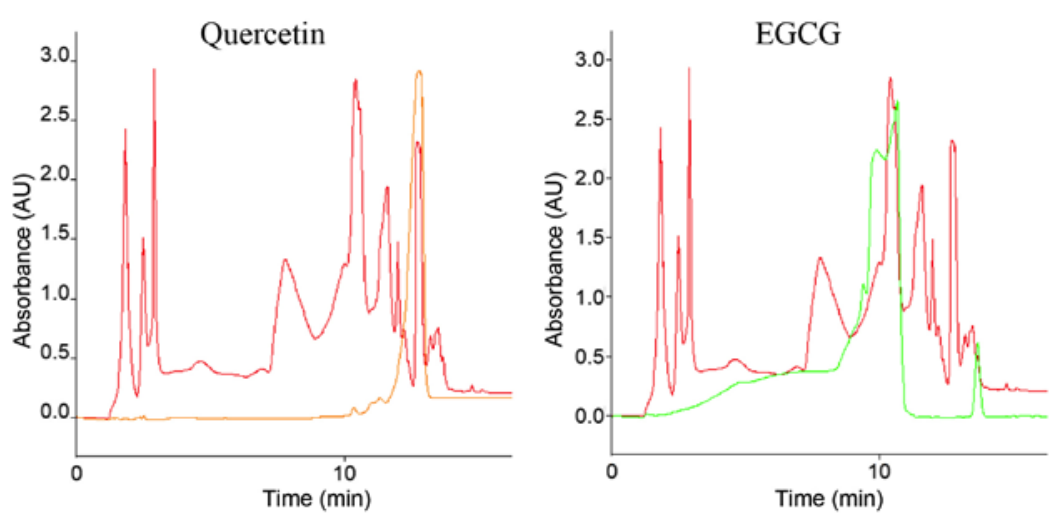

Figure 1. HPLC results in AU/min (ordinate = Absorbance in absorbance unit (AU), abscissa $=$ time in min). MT dissolved in $70 \%$ ethanol (red), quercetin dissolved in 50\% DMSO (orange) and MT dissolved in 70\% ethanol (red), EGCG dissolved in aquadest (green). MT, matcha tea; EGCG, epigallocatechin gallate; HPLC, high-performance liquid chromatography.

Theory/calculation. The results were tested for normal distribution using the Kolmogorov-Smirnov test. Subsequently, one-factor variance analysis (ANOVA, analysis of variance) was carried out using with Bonferroni's post-hoc test. The statistics program IBM SPSS Statistics version 22 (IBM Corp., Armonk, NY, USA) was used for these analyses. A significance level of $\alpha=0.05$ and a confidence interval of $95 \%$ were selected. Significant differences were examined between the respective test results and negative controls with the corresponding solvent, as well as between the two cell lines. The calculation of the correlations took place for interval-scaled features using the Pearsonian dimension correlation coefficient with MS Excel 2010 . A very high correlation was assumed to be $r>0.9$.

\section{Results}

HPLC. For each tea extract and pure substance, three measurements were performed. Fig. 1 shows as an example the superimposed HPLC graph of one tea extract + one pure substance. Superimposed peaks represent similar retention times, assuming that the two covering peaks are the same substance.

Quercetin and EGCG could be detected in MT and in GT in ethanol, as well as dissolved in $\mathrm{H}_{2} \mathrm{O}$, using HPLC. The retention times for quercetin were $12.9 \mathrm{~min}$ in each case and $10.7 \mathrm{~min}$ for EGCG. The concentrations of EGCG and quercetin in the respective tea extracts were calculated based on the respective peak areas. The results given are the mean values of two test series. Table I demonstrates the obtained concentrations.

ATP luminescence test/CellTiter-Glo ${ }^{\circledR}$ test. Tea extracts exhibited a significant inhibitory effect on cell viability $(\mathrm{CV})$ in MDA-MB-231 cells in ethanol and water (Fig. 2A). Cell viability $(\mathrm{CV})$ was below $2 \%$ using tea extracts. Using the mixture of EGCG and quercetin (Mix), significant inhibition of cell viability occurred $(\mathrm{CV}=32 \%, \mathrm{SD}=2.1)$. Quercetin alone did not reach the $\mathrm{ED}_{50}$ at all of the measured concentrations and inhibited cell viability only at $30 \mu \mathrm{g} / \mathrm{ml}(\mathrm{CV}=61.3 \%$; $\mathrm{SD}=2.8$ ). Different EGCG concentrations revealed a doseresponse relationship (correlation $\mathrm{r}=0.96$, i.e., the amount at $r>0.9$ ). With increasing concentrations, the inhibition of cell
Table I. Concentrations of EGCG and quercetin in $\mathrm{mg} / \mathrm{ml}$ in the tea extracts $\left(0.3 \mathrm{~g}\right.$ of tea/ $\left.1 \mathrm{ml} \mathrm{H}_{2} \mathrm{O}\right)$.

\begin{tabular}{lcc}
\hline & EGCG & Quercetin \\
\hline MT in 70\%-ethanol & 13.5 & 1 \\
GT in 70\%-ethanol & 15.6 & 1.1 \\
MT in $\mathrm{H}_{2} \mathrm{O}$ & 6 & 1.2 \\
GT in $\mathrm{H}_{2} \mathrm{O}$ & 11 & 1.1 \\
Mean & 11.5 & 1.1 \\
\hline
\end{tabular}

EGCG, epigallocatechin gallate; MT, matcha tea; GT, green tea.

viability increased significantly for all measurements. The concentrations of $180,150,120$ and $90 \mu \mathrm{g} / \mathrm{ml}$ were above $\mathrm{ED}_{50}$. Estradiol did not significantly alter cell viability $(98.7 \%$, $\mathrm{SD}=5.6)$. Tamoxifen significantly inhibited the cell viability of MDA-MB-231 cells above the $\mathrm{ED}_{50}(\mathrm{CV}<1 \%)$.

The results using MCF-7 cells were similar to those using the MDA-MB-231 cell line (Fig. 2B). All tea extracts were above the $\mathrm{ED}_{50}(\mathrm{CV}<2 \%)$, similar to the mixture of EGCG and quercetin (Mix) $(\mathrm{VC}=33.2 \% ; \mathrm{SD}=13.6)$. In contrast to MDA-MB-231 cells, quercetin demonstrated an inhibitory effect beginning at a concentration of $10 \mu \mathrm{g} / \mathrm{ml}(\mathrm{CV}=81.5$, $\mathrm{SD}=7.1)$. As in MDA-MB-231 cells, a dose-response relationship was observed for different EGCG concentrations (correlation $\mathrm{r}=0.97$, i.e., the amount at $\mathrm{r}>0.97$ ). At concentrations of 90 to $180 \mu \mathrm{g} / \mathrm{ml}$, the $\mathrm{ED}_{50}$ was reached. At lower concentrations up to $45 \mu \mathrm{g} / \mathrm{ml}$, significant results were obtained. Estradiol led to slight cell proliferation $(\mathrm{CV}=107.3 \%$, $\mathrm{SD}=3.0$ ), and tamoxifen caused strong significant inhibition $(\mathrm{CV}=0.2 \%, \mathrm{SD}=0.0)$. Comparing the results of MDA-MB-231 and MCF-7 cells, a significant difference between the two cell lines was found only in the result for quercetin at $30 \mu \mathrm{g} / \mathrm{ml}$.

MTT assay. Tea extracts dissolved in ethanol had an inhibitory effect on MDA-MB-231 cells in both solvents and all, besides those in water, were above the $\mathrm{ED}_{50}$ (GT Eth: $\mathrm{CV}=40.1 \%$, $\mathrm{SD}=6.9$; $\mathrm{GT} \mathrm{H}_{2} \mathrm{O}: \mathrm{CV}=41.2 \%, \mathrm{SD}=15.3$; Matcha $\mathrm{H}_{2} \mathrm{O}$ : $\mathrm{CV}=54.4 \%, \mathrm{SD}=12.7$ (Fig. 3A). The mixture (Mix) of quercetin 

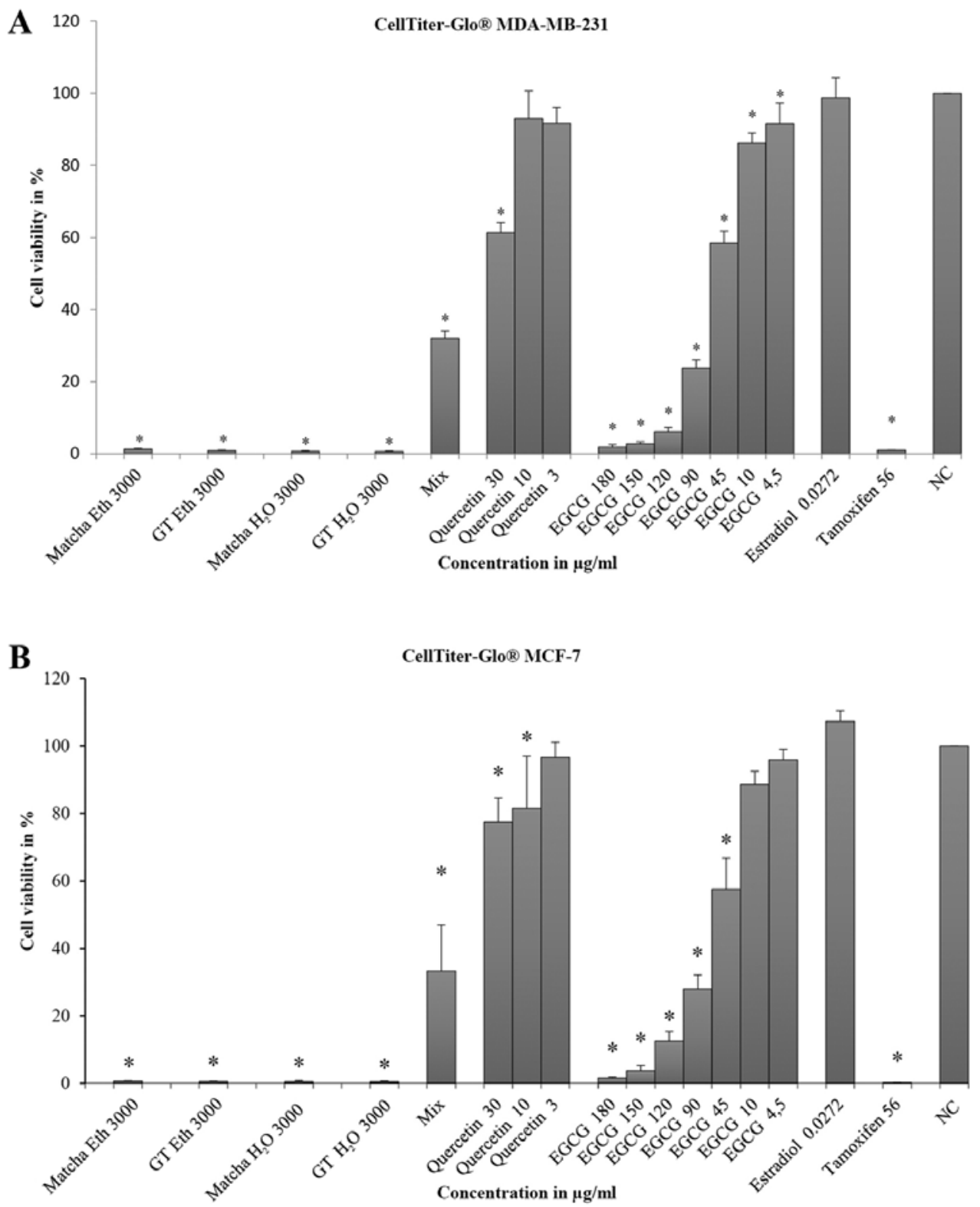

Figure 2. Measurement of adenosine triphosphate (ATP) with CellTiter-Glo ${ }^{\circledast}$ after $24 \mathrm{~h}$ in (A) MDA-MB-231 and (B) MCF-7 cells. Eth, dissolved in $70 \%$ ethanol; $\mathrm{H}_{2} \mathrm{O}$, dissolved in water; Mix, mixture of EGCG + quercetin, GT, green tea. The effects of quercetin and EGCG at different concentrations and estradiol and tamoxifen as controls on the cell viability relative to the negative control (NC) (100\%). Mean values with positive standard deviations are represented. $\mathrm{P}<0.05$.

and EGCG significantly inhibited cell viability but did not reach the $\mathrm{ED}_{50}(\mathrm{CV}=59.0 \%, \mathrm{SD}=12.2)$. In the case of quercetin, a dose-response relationship was found, although statistical significance was only obtained at $30 \mu \mathrm{g} / \mathrm{ml}(\mathrm{CV}=64.0 \%$, $\mathrm{SD}=13.3)$. Although the cell viability was significantly inhibited at $45-180 \mu \mathrm{g} / \mathrm{ml}$ of EGCG, the $\mathrm{ED}_{50}$ could not be reached. Estradiol had no effect on cell viability compared with the negative control $(\mathrm{CV}=100.8 \%, \mathrm{SD}=4.8)$ and tamoxifen was well above the $\mathrm{ED}_{50}(\mathrm{CV}=2.3$; $\mathrm{SD}=0.6)$.

In MCF-7 cells, tea extracts achieved significant inhibition of cell viability $\left(>\mathrm{ED}_{50}\right)$, $\left(\right.$ Matcha $\mathrm{H}_{2} \mathrm{O}: \mathrm{CV}=32.4 \%$ and $\mathrm{SD}=4.1$; GT $\mathrm{H}_{2} \mathrm{O}: \mathrm{CV}=20.7 \%$ and $\mathrm{SD}=2.1$; Matcha $\mathrm{Eth}: \mathrm{CV}=47.1 \%$ and $\mathrm{SD}=2.6$; GT Eth: $\mathrm{CV}=30.8 \%$ and $\mathrm{SD}=1.6$ ) (Fig. 3B). The mixture $(E G C G+$ quercetin $=$ Mix $)$ had little effect on cell viability $(\mathrm{CV}=91.4 \%, \mathrm{SD}=2.0)$. Quercetin caused no significant inhibition of cell viability; 3 and $10 \mu \mathrm{g} / \mathrm{ml}$ fell above the value of the negative control $(3 \mu \mathrm{g} / \mathrm{ml}: \mathrm{CV}=116.6, \mathrm{SD}=9.1,10 \mu \mathrm{g} / \mathrm{ml}$ : $\mathrm{CV}=101.6, \mathrm{SD}=5.3)$. Only at $30 \mu \mathrm{g} / \mathrm{ml}$ was minimal inhibition noticed (CV=99\%, $\mathrm{SD}=7.6)$. EGCG only demonstrated significant inhibition of viability at $180 \mu \mathrm{g} / \mathrm{ml}(\mathrm{CV}=66.0, \mathrm{SD}=24.9)$. Concentrations between 45 and $4.5 \mu \mathrm{g} / \mathrm{ml}$ had no effect with CV values above $100 \%$.

Comparing the MTT test results of MDA-MB-231 and MCF-7 cells, a significant difference between the two cell lines was found for quercetin at concentrations of 3 and $30 \mu \mathrm{g} / \mathrm{ml}$ and for EGCG at concentrations of 45 and $90 \mu \mathrm{g} / \mathrm{ml}$.

BrdU assay. In MDA-MB-231 cells, significant inhibitory effects were only demonstrated using the mixture (EGCG + quercetin $=$ Mix $)($ cell proliferation $(\mathrm{CP})=51.9 \%, \mathrm{SD}=16.8)$ and 

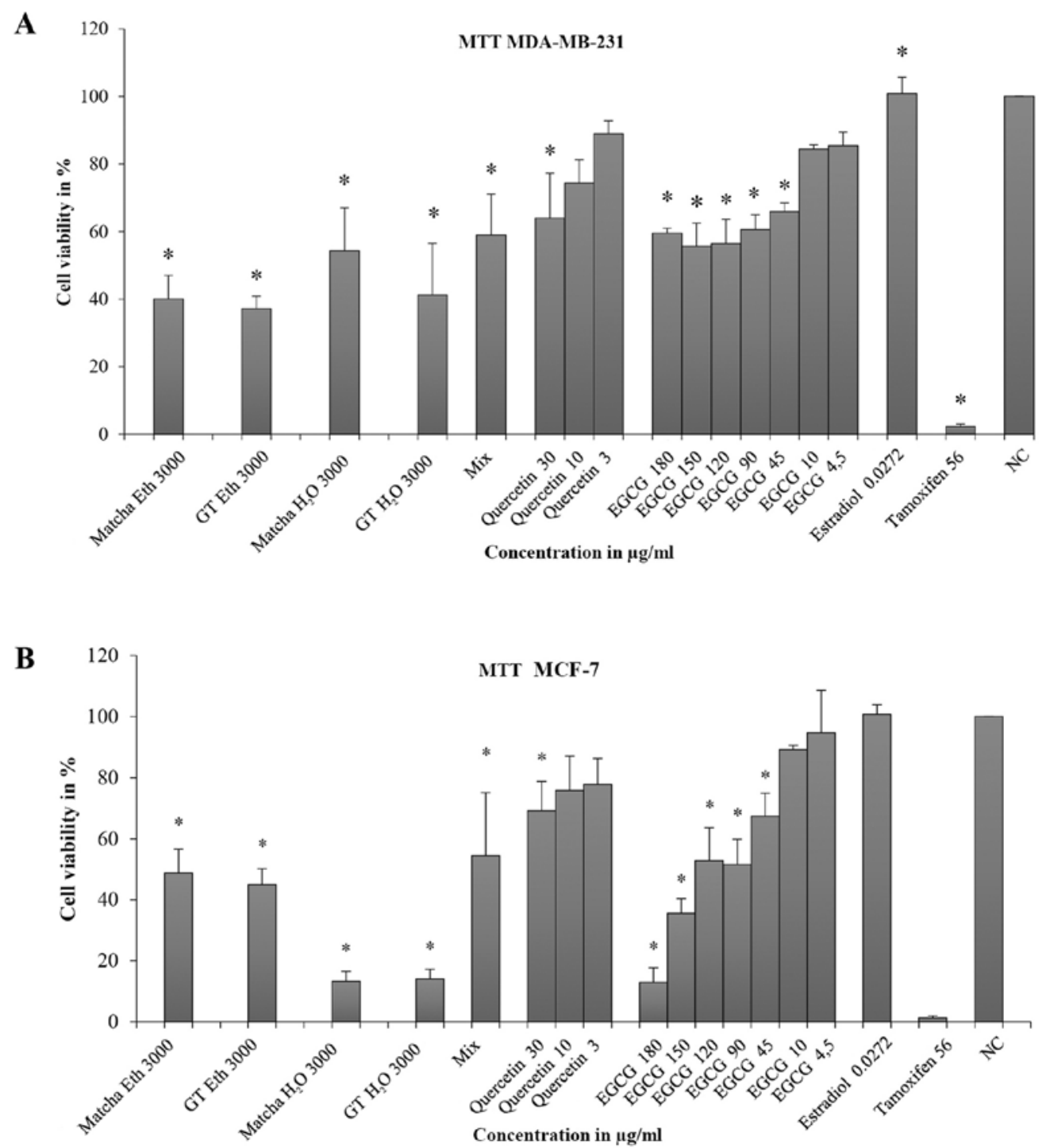

Figure 3. MTT test after $48 \mathrm{~h}$ in (A) MDA-MB-231 and (B) MCF-7 cells. (Eth $=$ dissolved in $70 \%$ ethanol, $\mathrm{H}_{2} \mathrm{O}=$ dissolved in water), mixture (EGCG + quercetin). The effects of quercetin and EGCG at different concentrations and of estradiol and tamoxifen as controls on the viability relative to the negative control (NC) (100\%). The mean values with positive standard deviations are represented. ${ }^{*} \mathrm{P}<0.05$.

tamoxifen $(\mathrm{CP}=1.0 \% ; \mathrm{SD}=0.2)$ (Fig. $4 \mathrm{~A})$. The $\mathrm{ED}_{50}$ was only reached using tamoxifen. The results for quercetin showed a dose-response relationship $(30 \mu \mathrm{g} / \mathrm{ml}: \mathrm{CP}=84.2 \%, \mathrm{SD}=5.0$; $10 \mu \mathrm{g} / \mathrm{ml}: \mathrm{CP}=85.1 \%, \mathrm{SD}=2.7 ; 3 \mu \mathrm{g} / \mathrm{ml}: \mathrm{CP}=87.1 \%, \mathrm{SD}=5.9$ ). Estradiol showed a strong positive effect on cell proliferation $(\mathrm{CP}=0.71 \%, \mathrm{SD}=0.23)$ compared with the negative control (NC) $(\mathrm{CP}=101.7 \%, \mathrm{SD}=4.7)$.

In the BrdU test for MCF-7, the $\mathrm{ED}_{50}$ was not reached by any of the extracts except tamoxifen $(\mathrm{CP}=2.7 \%, \mathrm{SD}=1.3)$ (Fig. 4B). At the lowest concentrations of quercetin $(3 \mu \mathrm{g} / \mathrm{ml}$ : $\mathrm{CP}=105.2 \%, \mathrm{SD}=2.7)$ and $\mathrm{EGCG}(4.5 \mu \mathrm{g} / \mathrm{ml}: \mathrm{CP}=111.7 \%$, $\mathrm{SD}=1.1)$ a proliferation-promoting effect was observed.

Neutral Red test. In MDA-MB-231 cells, a clear difference in the strength of inhibition between the tea extracts dissolved in ethanol or water was demonstrated (Fig. 5A). While the extracts dissolved in water showed strong inhibition of cell viability $(\mathrm{CV})$ of $22.6 \%(\mathrm{SD}=2.6)$ in $\mathrm{GT}$ and $25.8 \%(\mathrm{SD}=4.1)$ in MT, ethanol extracts (Eth) only demonstrated a slight inhibition of $44.3 \%(\mathrm{SD}=5.5)$ in $\mathrm{GT}$ and $55.1 \%(\mathrm{SD}=7.2)$ in MTE. Statistical significance was achieved with all tea extracts. EGCG showed significant inhibition of cell viability at concentrations of $45-180 \mu \mathrm{g} / \mathrm{ml}$, but the $\mathrm{ED}_{50}$ was reached only at $180 \mu \mathrm{g} / \mathrm{ml}$.

In MCF-7 cells, as in the case of MDA-MB-231 cells, it was demonstrated that tea extracts dissolved in water (Matcha $\mathrm{H}_{2} \mathrm{O}: \mathrm{CV}=13.3 \%$; $\mathrm{SD}=3.3$; $\mathrm{GT} \mathrm{H}_{2} \mathrm{O}: \mathrm{CV}=14.0 \%$, $\mathrm{SD}=3.2$ ) have a significantly more potent inhibitory effect on cell viability than when dissolved in ethanol (Matcha Eth: $\mathrm{CV}=45.0 \%$, $\mathrm{SD}=5.2$; GT Eth: $\mathrm{CV}=48.8 \%, \mathrm{SD}=7.8$ ) (Fig. $5 \mathrm{~B}$ ).

For EGCG, the $\mathrm{ED}_{50}$ was reached at $180 \mu \mathrm{g} / \mathrm{ml}(\mathrm{CV}=13.0 \%$, $\mathrm{SD}=4.8), 150 \mu \mathrm{g} / \mathrm{ml}(\mathrm{CV}=35.5 \%, \mathrm{SD}=4.8)$ and $90 \mu \mathrm{g} / \mathrm{ml}$ $(\mathrm{CV}=\%, \mathrm{SD}=7.1)$. Quercetin led to a significant inhibition of viability only at the highest concentration used $(\mathrm{CV}=69.2 \%$, $\mathrm{SD}=9.5$ ). None of the extracts led to an increase in viability $(>100 \%)$; only the result for estradiol was similar to that for the negative control (NC) $(\mathrm{CV}=100.7 \%, \mathrm{SD}=3.2)$. Tamoxifen treatment resulted in only $1.3 \%$ cell viability. 

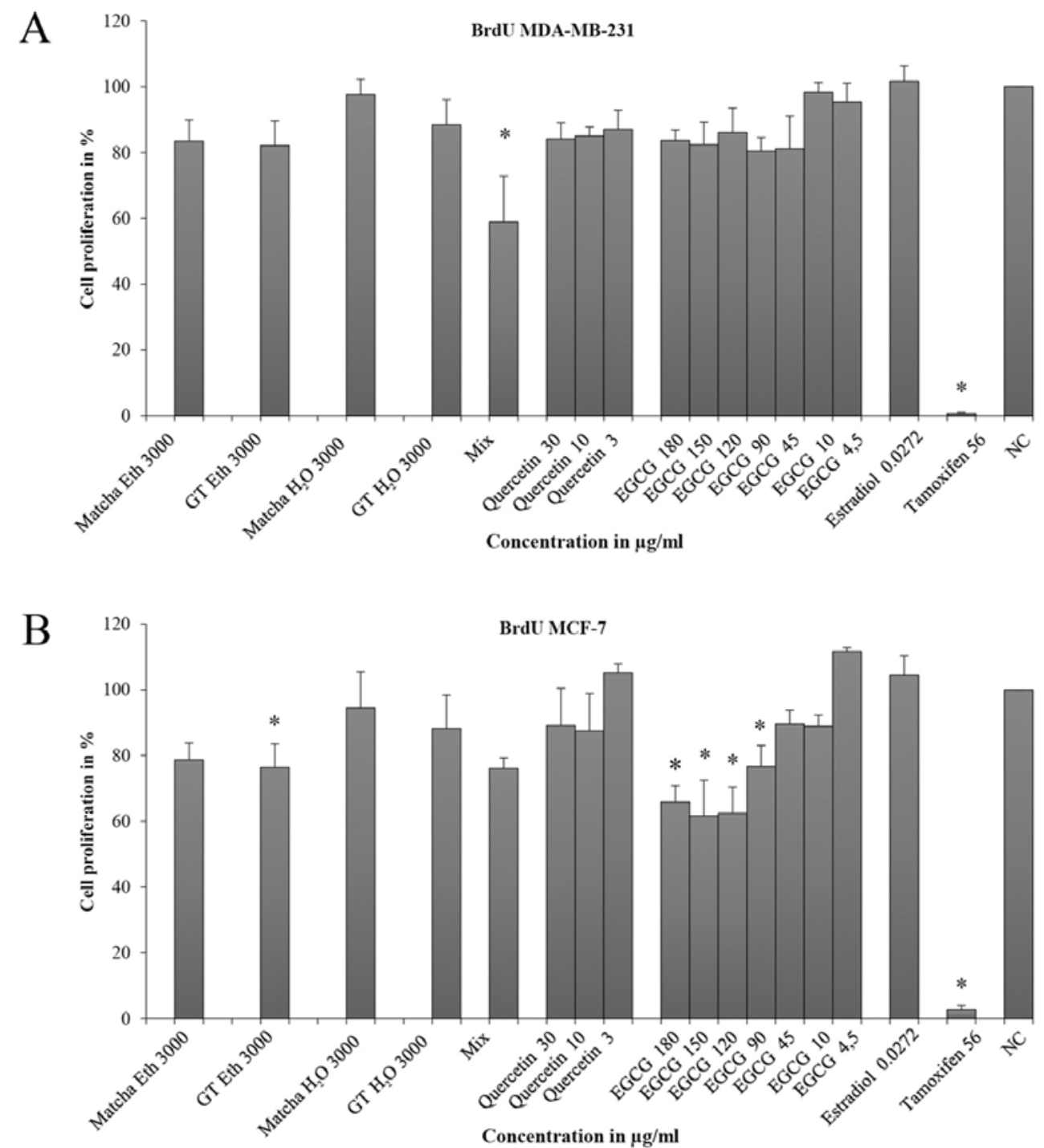

Figure 4. Cell proliferation in (A) MDA-MB-231 and (B) MCF-7 cells. BrdU test after $24 \mathrm{~h}$; (Eth = Dissolved in 70\% ethanol, $\mathrm{H}_{2} \mathrm{O}=$ dissolved in water), mixture (EGCG + quercetin). Effect of quercetin and EGCG at different concentrations and of estradiol and tamoxifen as controls on the cell viability relative to the negative control (NC) (100\%). The mean values with positive standard deviations are represented. ${ }^{*} \mathrm{P}<0.05$.

Oxidative stress. The oxidative stress test was used to evaluate the metabolism of the cells. As an indicator of oxidative stress, an increase in the $\mathrm{H}_{2} \mathrm{O}_{2}$ concentration was measured in the cell culture.

It was found that in all extract suspensions, the concentration of $\mathrm{H}_{2} \mathrm{O}_{2}$ increased compared with that in the negative control. GT extracts dissolved in ethanol resulted in the strongest increase in $\mathrm{H}_{2} \mathrm{O}_{2}$ (up to 1.7 times the values observed in the control). EGCG also showed a factor of 1.5 increase in the $\mathrm{H}_{2} \mathrm{O}_{2}$ concentration (data not shown).

Similar to MDA-MB-231 cells, the GT extracts dissolved in ethanol and EGCG extract showed the highest $\mathrm{H}_{2} \mathrm{O}_{2}$ concentrations in MCF-7 cells compared with those in the negative control with a maximum 1.5-fold increase.

\section{Discussion}

This study confirmed that EGCG and quercetin are contained in GT and that the single substances, as well as GT itself, have an anticarcinogenic effect on both ER/PR receptor-positive and -negative breast cancer cells, suggesting estrogen receptorindependent pathways.

EGCG is the most abundant anticarcinogenic catechin in GT (4). In the German breast cancer guideline of 2012, EGCG has been previously described as a complementary drug used by patients that should not be applied outside of clinical trials (16). In the ATP luminescence test, a correlative $(|r|=0.97)$ concentration-dependent inhibition of cell viability was observed in both cell lines. At the highest concentration tested, the effect of EGCG corresponded with that of tamoxifen. Wang et al performed the same ATP assay with MCF-7 cells and EGCG, testing EGCG concentrations between 4.5 and $54 \mu \mathrm{g} / \mathrm{ml}$. These researchers' results showed an inhibition of cell viability even at low concentrations after $24 \mathrm{~h}$. In the MTT assay, Wang et al reported viability values after $48 \mathrm{~h}$ that are comparable to those of our study (18). In MDA-MB-231 cells, Thangapazham et al (17) described lower viability values in the MTT assay with EGCG at different 

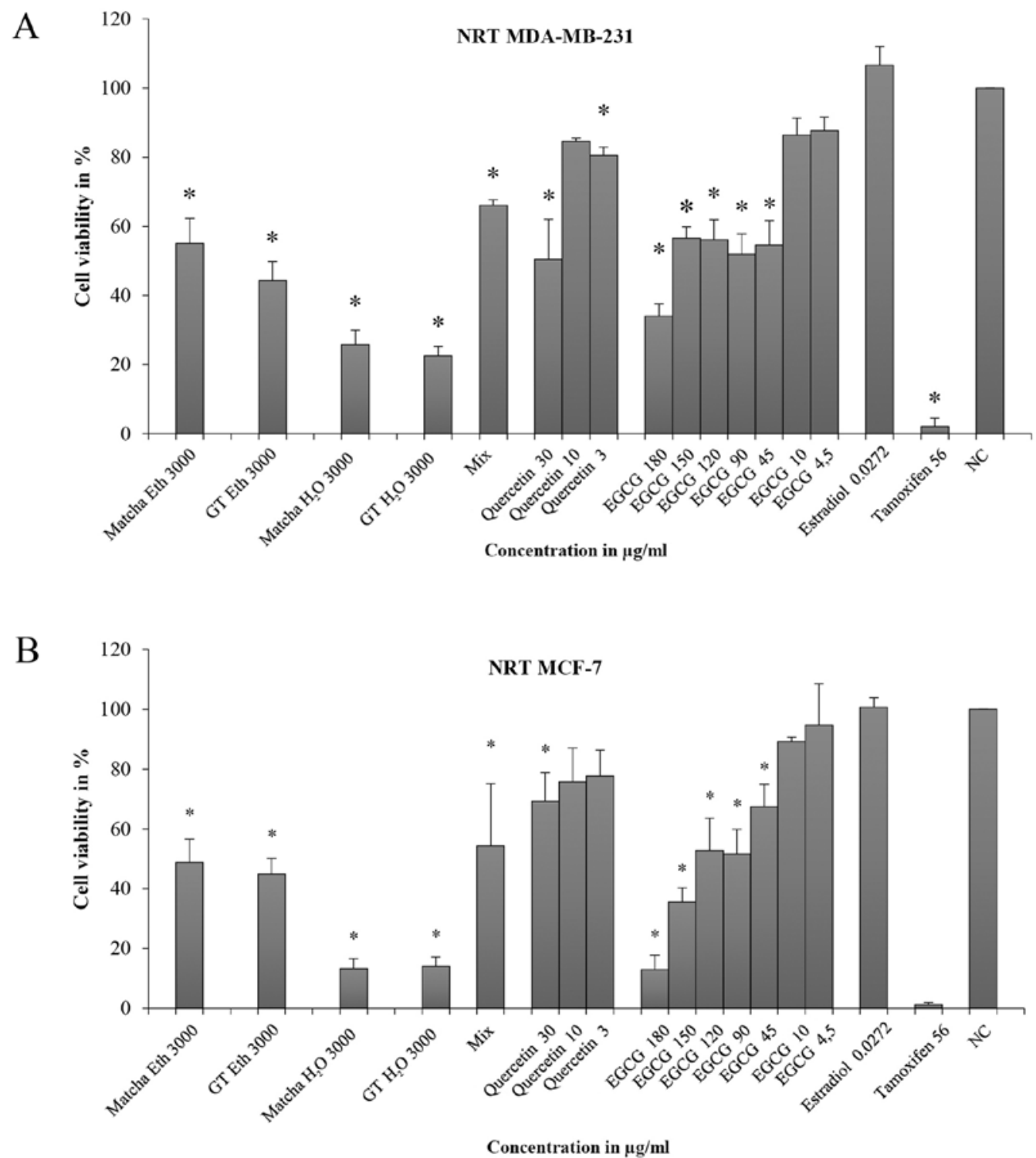

Figure 5. Cell viability in (A) MDA-MB-231 and (B) MCF-7 cells. Neutral Red Test; (Eth = dissolved in 70\% ethanol, $\mathrm{H}_{2} \mathrm{O}=$ dissolved in water), mixture (EGCG + quercetin). Effect of quercetin and EGCG at different concentrations and of estradiol and tamoxifen as controls on the viability relative to the negative control (NC) (100\%). The mean values with positive standard deviations are represented. ${ }^{*} \mathrm{P}<0.05$.

concentrations after $48 \mathrm{~h}$. The $\mathrm{ED}_{50}$ was reached at $\mathrm{EGCG}$ $50 \mu \mathrm{g} / \mathrm{ml}$; however, in this study, the $\mathrm{ED}_{50}$ was not achieved by any of the tested concentrations. In the studies of both Wang et al and Thangapazham et al, the measurements were also carried out after 24, 48 and $72 \mathrm{~h}$, and even $96 \mathrm{~h}$, as reported by Thangapazham et al. All of the results showed that the cell viability was decreased further over time. An explanation for the difference in viability values, despite identical test methods and identical EGCG concentrations, could be the $\mathrm{pH}$ value. As early as 1997, Zhu et al reported that catechins are considerably more stable at acidic $\mathrm{pH}$ values than at alkaline $\mathrm{pH}$ values (19). Our $\mathrm{pH}$ measurements always showed alkaline $\mathrm{pH}$ values, suggesting instability of the EGCG molecules. In the investigations of Wang et al and Thangapazham et al, no information was available on the $\mathrm{pH}$ values of the cell cultures. Therefore, it is possible that they worked at lower $\mathrm{pH}$ values, leading to higher stability of the catechins and increased inhibition of cellular viability.
Not every EGCG concentration in the BrdU test in MCF-7 cells reached the $\mathrm{ED}_{50}$. However, in MDA-MB-231 cells, the mixture of EGCG and quercetin exhibited a stronger effect than the two single substances alone. An explanation could be the influence of the two substances on the PI3K/Akt/mTOR signaling pathway and thus on endothelial growth factor (VEGF). Van Aller et al (20) demonstrated that EGCG has an inhibitory effect on this signaling pathway in MDA-MB-231 cells. Bruning confirmed the inhibitory effect of quercetin on mTOR (21). Gu et al observed that the oral administration of EGCG in mice resulted in a VEGF-mediated reduction of tumor volume compared with the control group (22). Wang et al demonstrated in 2014, using a xenograft prostate tumor mouse model, that the combination of EGCG and quercetin resulted in greater bioavailability and lower methylation of the catechins. Tumor size could be reduced compared with that in the control groups. They also found that the quercetin and EGCG combination led to a significant reduction in phosphorylated AKT 
(pAKT) (23). Scandlyn et al combined EGCG with tamoxifen, provoking a reduction of mTOR by $78 \%$ in receptor-negative tumors in vivo (24).

Our results showed no significant differences between the effects of EGCG on estrogen receptor-negative MDA-MB-231 and ER-positive MCF-7 cells; therefore, it can be assumed that the effect is not, or at least not exclusively, generated via the estrogen receptor. Tachibana et al (26) and Umeda et al (25) found that EGCG exerts its anticarcinogenic effect on its binding behavior with the surface the $67-\mathrm{kDa}$ laminin receptor (67-LR). The 67-LR is important in the metastasis of tumor cells (27). Mittal et al showed that EGCG inhibits telomerase in MCF-7 cells, which is increased in more than $90 \%$ of all cases in tumors (28). Roy et al (29) described increased expression of p53 and the proapoptotic protein Bax, as well as reduced expression of the anti-apoptotic protein $\mathrm{Bcl}-2$ in estrogen receptor-negative breast cancer cells under EGCG influence. Moreover, although MDA-MB-231 cells are triple negative, these cells express ER $\beta$. Therefore, tamoxifen treatment is possible (30).

In the tests performed using GT and MT extracts, a reduction in cellular viability, vitality, and proliferation was observed (Fig. 2A and B). It is assumed that EGCG is responsible for most of the anticancer effects of GT $(4,31)$. As demonstrated in our results, Wang et al observed significantly higher viability values in the MTT assay than the ATP measurements (18). An explanation could be offered by the studies of Bruggisser et al (32) and Peng et al (48), who observed that antioxidants and flavonoids result in a reduced reaction of MTT to the dye formazan, even without the presence of living cells. The amount of formazan formed is measured photometrically, and false-high results are measured.

The flavonoid quercetin was detected by HPLC in GT. In almost all tests performed, inhibition of cell viability was demonstrated, except for the MCF-7 cells in the MTT assay, in which all results were above $100 \%$ cell viability but without a statistical significance. In a study by Scambia et al, quercetin inhibited the growth of MCF-7, as well as that of MDA-MB-231 cells, in a dose-dependent manner by binding to the estrogenbinding domain type II (EBS II) (33). Lee et al described that the induction of apoptosis of MCF-7 cells is caused by the formation of free oxygen radicals that activate the pro-apoptotic AMPKa1/ASK1/p38 signaling pathways (34). Duo et al recognized the apoptotic effect of quercetin in the upregulation of Bax protein and reduction of Bcl-2 protein (35). Similar to EGCG, quercetin also has an inhibitory effect on the mTOR signal cascade (36).

As already mentioned, EGCG is a very sensitive molecule. It is assumed that EGCG changes its structure under cell culture conditions by auto-oxidation and dimerization. Sang et al observed increased instability of the EGCG molecule in normal tap water, attributable to its iron constituents (37). Other factors that influence the molecular stability are $\mathrm{pH}$, temperature and the concentration of EGCG (20,37). Sang et al demonstrated that $20 \mu \mathrm{mol} / \mathrm{l}$ of EGCG in RPMI-1640 medium (named after the Roswell Park Memorial Institute), similar to the DMEM used in our work, lost integrity after $1 \mathrm{~h}$ at $37^{\circ} \mathrm{C}$. At high concentrations, EGCG tends to change the stereoconformation and become GCG (gallocatechingallate) and the molecules' half-life is prolonged. At lower concentrations, dimer formation occurs, resulting in molecular instability. Inconsistent amounts of time passed between the preparation and measurement may contribute to the heterogeneous results in the literature on the amount of EGCG in a cup of tea, presuming that some of the EGCG may have already decayed after the preparation of the extracts at the time of the determination of the quantity (37).

Importantly, this study was performed in vitro; therefore, the bioavailability of EGCG in humans was not considered. Yang et al found in a patient study $(\mathrm{n}=18)$ that the consumption of $3 \mathrm{~g}$ of decaffeinated GT (EGCG content: $73 \mathrm{mg} / \mathrm{g}$ ) resulted in a plasma concentration of no more than $326 \mathrm{ng} / \mathrm{ml}$. However, an increase from 1.5 to $3 \mathrm{~g}$ resulted in a triple EGCG plasma concentration; a further increase at a dose of $4.5 \mathrm{~g}$ could not be observed. Thus, it appears that a saturation of EGCG uptake is achieved around $3 \mathrm{~g}$ (38). Chow et al tested the bioavailability of EGCG by administering EGCG capsules. They measured the plasma levels of $439 \mathrm{ng} / \mathrm{ml}$ after administering $800 \mathrm{mg}$ of EGCG or $388 \mathrm{ng} / \mathrm{ml}$ after the administering $800 \mathrm{mg}$ of uncontaminated EGCG (polyphenol E) (39). These results show that the bioavailability of EGCG in plasma is very low.

One way to increase EGCG bioavailability is described by Landis-Piwowar et al, who demonstrated in vitro as well as in animal experiments in vivo that a prodrug of EGCG, in which the hydroxyl groups were protected by peracetic acid groups before methylation, leads to greater bioavailability and results in higher concentrations in breast cancer cells (40). Moreover, in 2007, they found that the methylation of EGCG by catechol $O$-methyltransferase (COMT) leads to decreased anticarcinogenic activity of the catechins (41). This observation was also consistent with the work of Wu et al who demonstrated that predominantly, carriers of the COMT-L allele, a low-activity form of COMT, benefited from the anti-carcinogenic effects of the catechins; however, in carriers of the highly active COMT-H allele, there was no difference in breast cancer risk between tea consumers and non-consumers (42). LandisPiwowars et al demonstrated that, in MDA-MB-231 cells expressing the COMT-H form, the effect of catechins can be increased using COMT inhibitors (43).

In conclusion, based on our results and the findings reported in the literature, the anti-carcinogenic activity by GT and its components EGCG and quercetin can be assumed.

A problem in the therapeutic setting of EGCG is the low oral bioavailability. In animal studies (e.g., in athymic mice), the possibility of intravenous EGCG administration to avoid the first-pass effect could be tested (44). Another approach would be to administer an EGCG prodrug, as described by Landis-Piwowar et al, leading to better bioavailability (40).

However, more studies are crucial to determine the potential toxicity of EGCG at higher doses, as hepatotoxic effects at high concentrations are described. The drug interactions of EGCG and associated risks, e.g., effects of the pharmacokinetics of concomitant medication by influencing enzymes such as the cytochrome P450 system, need further evaluation (45). It is also worth including Her-2 positive cell lines in further studies. But for this study, we focused on ER $\alpha / E R \beta$-positive cells.

EGCG and tamoxifen could represent a promising combination in breast cancer therapy as synergistic anti-proliferative and cytotoxic effects in both MCF-7 and MDA-MB-231 cells 
were observed $(46,47)$. Scandlyn et al observed an antiproliferative effect of EGCG in combination with low tamoxifen doses $(75 \mu \mathrm{g} / \mathrm{kg})$ in animals with triple-negative breast cancer (24). To better understand this effect, active compounds of the two substances and pathways associated should be investigated more intensively. Therefore, studies regarding the influence on apoptosis and neovascularization should be considered. To understand the mode of action of EGCG, it would be interesting to further investigate the role of the $67-\mathrm{kDa}$ laminin receptor $(25,27)$.

\section{Acknowledgements}

Not applicable.

\section{Funding}

The presents tudy was funded by the Department of Obstetrics and Gynecology of the LMU Munich and by the 'Deutsche Krebshilfe' for D.U. Richter.

\section{Availability of data and materials}

The datasets used during the present study are available from the corresponding author upon reasonable request.

\section{Authors' contributions}

LS and PM performed the experiments. SH added additional experiments. DUR conceived and designed the study. JGK, $\mathrm{HH}, \mathrm{TV}, \mathrm{TPB}, \mathrm{SM}$ and UJ were also involved in the conception of the study and revised it critically. All authors read and approved the manuscript and agree to be accountable for all aspects of the research in ensuring that the accuracy or integrity of any part of the work are appropriately investigated and resolved.

\section{Ethics approval and consent to participate}

Not applicable.

\section{Patient consent for publication}

Not applicable.

\section{Competing interests}

The authors declare no competing interests.

\section{References}

1. Wolf A, Bray GA and Popkin BM: A short history of beverages and how our body treats them. Obes Rev 9: 151-164, 2008.

2. A B. Beling A Jahresbericht_2015 n.d.; 250516:Lay.

3. Fujioka K, Iwamoto T, Shima H, Tomaru K, Saito H, Ohtsuka M, Yoshidome A, Kawamura Y and Manome Y: The powdering process with a set of ceramic mills for green tea promoted catechin extraction and the ROS inhibition effect. Molecules 21: 474, 2016.

4. Cabrera C, Artacho R and Giménez R: Beneficial effects of green tea: a review. J Am Coll Nutr 25: 79-99, 2006.

5. Tachibana H: Molecular basis for cancer chemoprevention by green tea polyphenol EGCG. Forum Nutr 61: 156-169, 2009.
6. Belitz HD, Grosch W and Schieberle P: Food Chemistry 4th edition. Springer-Verlag Berlin Heidelberg. https://doi. org/10.1007/978-3-40-69934-7.

7. Stangl V, Lorenz M and Stangl K: The role of tea and tea flavonoids in cardiovascular health. Mol Nutr Food Res 50: 218-228, 2006.

8. Bhagwat S, Haytowitz DB, Holden JM. USDA Database for the Flavonoid Content of Selected Foods. 2011.

9. Hallman K, Aleck K, Quigley M, Dwyer B, Lloyd V, Szmyd M and Dinda $S$ : The regulation of steroid receptors by epigallocatechin-3-gallate in breast cancer cells. Breast Cancer (Dove Med Press) 9: 365-373, 2017.

10. Wu M, Liu D, Zeng R, Xian T, Lu Y, Zeng G, Sun Z, Huang B and Huang Q: Epigallocatechin-3-gallate inhibits adipogenesis through down-regulation of PPAR $\gamma$ and FAS expression mediated by PI3K-AKT signaling in 3T3-L1 cells. Eur J Pharmacol 795: 134-142, 2017.

11. Ding ML, Ma H, Man YG and Lv HY: Protective effects of a green tea polyphenol, epigallocatechin-3-gallate, against sevoflurane-induced neuronal apoptosis involve regulation of CREB/ $\mathrm{BDNF} / \mathrm{TrkB}$ and $\mathrm{PI} 3 \mathrm{~K} / \mathrm{Akt} / \mathrm{mTOR}$ signalling pathways in neonatal mice. Can J Physiol Pharmacol 95: 1396-1405, 2017.

12. Rashidi B, Malekzadeh M, Goodarzi M, Masoudifar A and Mirzaei H: Green tea and its anti-angiogenesis effects. Biomed Pharmacother 89: 949-956, 2017.

13. Li YF, Wang H, Fan Y, Shi HJ, Wang QM, Chen BR, Khurwolah MR, Long QQ, Wang SB, Wang ZM, et al: Epigallocatechin-3-gallate inhibits matrix metalloproteinase-9 and monocyte chemotactic protein-1 expression through the $67-\mathrm{kDa}$ laminin receptor and the TLR4/MAPK/NF- $\mathrm{KB}$ signalling pathway in lipopolysaccharide-induced macrophages. Cell Physiol Biochem 43: 926-936, 2017.

14. Moradzadeh M, Hosseini A, Erfanian S and Rezaei H: Epigallocatechin-3-gallate promotes apoptosis in human breast cancer T47D cells through down-regulation of PI3K/AKT and Telomerase. Pharmacol Rep 69: 924-928, 2017.

15. Huang CY, Han Z, Li X, Xie HH and Zhu SS: Mechanism of EGCG promoting apoptosis of MCF-7 cell line in human breast cancer. Oncol Lett 14: 3623-3627, 2017.

16. S3 Leitlinie Mammakarzinom: n.d. https://www.awmf.org/ uploads/tx_szleitlinien/032-045OL1_S3_Mammakarzinom_2018-09. pdf.

17. Thangapazham RL, Singh AK, Sharma A, Warren J, Gaddipati JP and Maheshwari RK: Green tea polyphenols and its constituent epigallocatechin gallate inhibits proliferation of human breast cancer cells in vitro and in vivo. Cancer Lett 245: 232-241, 2007.

18. Wang P, Henning SM and Heber D: Limitations of MTT and MTS-based assays for measurement of antiproliferative activity of green tea polyphenols. PLoS One 5: e10202, 2010.

19. Zhu QY, Zhang A, Tsang D, Huang Y and Chen Z-Y: Stability of Green Tea Catechins. J Agric Food Chem 45: 4624-4628, 1997.

20. Van Aller GS, Carson JD, Tang W, Peng H, Zhao L, Copeland RA, Tummino PJ and Luo L: Epigallocatechin gallate (EGCG), a major component of green tea, is a dual phosphoinositide3-kinase/mTOR inhibitor. Biochem Biophys Res Commun 406: 194-199, 2011.

21. Bruning A: Inhibition of mTOR signaling by quercetin in cancer treatment and prevention. Anticancer Agents Med Chem 13: 1025-1031, 2013

22. Gu JW, Makey KL, Tucker KB, Chinchar E, Mao X, Pei I, Thomas EY and Miele L: EGCG, a major green tea catechin suppresses breast tumor angiogenesis and growth via inhibiting the activation of HIF- $1 \alpha$ and NF- $\kappa \mathrm{B}$, and VEGF expression. Vasc Cell 5: 9, 2013

23. Wang P, Vadgama JV, Said JW, Magyar CE, Doan N, Heber D and Henning SM: Enhanced inhibition of prostate cancer xenograft tumor growth by combining quercetin and green tea. J Nutr Biochem 25: 73-80, 2014.

24. Scandlyn MJ, Stuart EC, Somers-Edgar TJ, Menzies AR and Rosengren RJ: A new role for tamoxifen in oestrogen receptornegative breast cancer when it is combined with epigallocatechin gallate. Br J Cancer 99: 1056-1063, 2008.

25. Umeda D, Yano S, Yamada K and Tachibana H: Green tea polyphenol epigallocatechin-3-gallate signaling pathway through 67-kDa laminin receptor. J Biol Chem 283: 3050-3058, 2008.

26. Tachibana H, Koga K, Fujimura Y and Yamada K: A receptor for green tea polyphenol EGCG. Nat Struct Mol Biol 11: 380-381, 2004.

27. Nelson J, McFerran NV, Pivato G, Chambers E, Doherty C, Steele D and Timson DJ: The $67 \mathrm{kDa}$ laminin receptor: Structure, function and role in disease. Biosci Rep 28: 33-48, 2008. 
28. Mittal A, Pate MS, Wylie RC, Tollefsbol TO and Katiyar SK EGCG down-regulates telomerase in human breast carcinoma MCF-7 cells, leading to suppression of cell viability and induction of apoptosis. Int J Oncol 24: 703-710, 2004.

29. Roy AM, Baliga MS and Katiyar SK: Epigallocatechin-3-gallate induces apoptosis in estrogen receptor-negative human breast carcinoma cells via modulation in protein expression of p53 and Bax and caspase-3 activation. Mol Cancer Ther 4: 81-90, 2005.

30. Madeira M, Mattar A, Logullo ÂF, Soares FA and Gebrim LH: Estrogen receptor alpha/beta ratio and estrogen receptor beta as predictors of endocrine therapy responsiveness-a randomized neoadjuvant trial comparison between anastrozole and tamoxifen for the treatment of postmenopausal breast cancer. BMC Cancer 13: 425, 2013.

31. Stuart EC, Scandlyn MJ and Rosengren RJ: Role of epigallocatechin gallate (EGCG) in the treatment of breast and prostate cancer. Life Sci 79: 2329-2336, 2006.

32. Bruggisser R, von Daeniken K, Jundt G, Schaffner W and Tullberg-Reinert H: Interference of plant extracts, phytoestrogens and antioxidants with the MTT tetrazolium assay. Planta Med 68: 445-448, 2002.

33. Scambia G, Ranelletti FO, Panici PB, Piantelli M, De Vincenzo R, Ferrandina G, Bonanno G, Capelli A and Mancuso S: Quercetin induces type-II estrogen-binding sites in estrogen-receptornegative (MDA-MB231) and estrogen-receptor-positive (MCF-7) human breast-cancer cell lines. Int J Cancer 54: 462-466, 1993.

34. Lee YK, Hwang JT, Kwon DY, Surh YJ and Park OJ: Induction of apoptosis by quercetin is mediated through AMPKalpha1/ASK1/ p38 pathway. Cancer Lett 292: 228-236, 2010.

35. Duo J, Ying GG, Wang GW and Zhang L: Quercetin inhibits human breast cancer cell proliferation and induces apoptosis via Bcl-2 and Bax regulation. Mol Med Rep 5: 1453-1456, 2012.

36. Klappan AK, Hones S, Mylonas I and Brüning A: Proteasome inhibition by quercetin triggers macroautophagy and blocks mTOR activity. Histochem Cell Biol 137: 25-36, 2012.

37. Sang S, Lee MJ, Hou Z, Ho CT and Yang CS: Stability of tea polyphenol (-)-epigallocatechin-3-gallate and formation of dimers and epimers under common experimental conditions. J Agric Food Chem 53: 9478-9484, 2005.
38. Yang CS, Chen L, Lee MJ, Balentine D, Kuo MC and Schantz SP: Blood and urine levels of tea catechins after ingestion of different amounts of green tea by human volunteers. Cancer Epidemiol Biomarkers Prev 7: 351-354, 1998.

39. Chow HHS, Cai Y, Alberts DS, Hakim I, Dorr R, Shahi F, Crowell JA, Yang CS and Hara Y: Phase I pharmacokinetic study of tea polyphenols following single-dose administration of epigallocatechin gallate and polyphenon E. Cancer Epidemiol Biomarkers Prev 10: 53-58, 2001.

40. Landis-Piwowar KR, Huo C, Chen D, Milacic V, Shi G, Chan TH and Dou QP: A novel prodrug of the green tea polyphenol (-)-epigallocatechin-3-gallate as a potential anticancer agent. Cancer Res 67: 4303-4310, 2007.

41. Landis-Piwowar KR, Wan SB, Wiegand RA, Kuhn DJ, Chan TH and Dou QP: Methylation suppresses the proteasome-inhibitory function of green tea polyphenols. J Cell Physiol 213: 252-260, 2007.

42. Wu AH, Tseng CC, Van Den Berg D and Yu MC: Tea intake, COMT genotype, and breast cancer in Asian-American women. Cancer Res 63: 7526-7529, 2003.

43. Landis-Piwowar K, Chen D, Chan TH and Dou QP: Inhibition of catechol-Omicron-methyltransferase activity in human breast cancer cells enhances the biological effect of the green tea polyphenol (-)-EGCG. Oncol Rep 24: 563-569, 2010.

44. Miyazawa T: Absorption, metabolism and antioxidative effects of tea catechin in humans. Biofactors 13: 55-59, 2000.

45. Schönthal AH: Adverse effects of concentrated green tea extracts. Mol Nutr Food Res 55: 874-885, 2011.

46. Chisholm K, Bray BJ and Rosengren RJ: Tamoxifen and epigallocatechin gallate are synergistically cytotoxic to MDA-MB-231 human breast cancer cells. Anticancer Drugs 15: 889-897, 2004.

47. Sakata M, Ikeda T, Imoto S, Jinno H and Kitagawa Y: Prevention of mammary carcinogenesis in $\mathrm{C} 3 \mathrm{H} / \mathrm{OuJ}$ mice by green tea and tamoxifen. Asian Pac J Cancer Prev 12: 567-571, 2011.

48. Peng L, Wang B and Ren P: Reduction of MTT by flavonoids in the absence of cells. Colloids Surf B Biointerfaces 45: 108-111, 2005. 